\section{Greens to shut Berlin reactor}

\section{Munich}

OpPONENTS of nuclear energy in Berlin are poised to shut down a research reactor and are threatening the future of an important research institution, the HahnMeitner Institute (HMI). HMI, named after Otto Hahn and Lise Meitner, who together with Fritz Strassmann discovered nuclear fission in Berlin in 1938-39, is the only West German national laboratory (Grossforschungseinrichtung) in West Berlin.

Last week, Environment Senator Michaele Schreyer of the Alternative Liste, the local branch of the environmentalist Green Party, refused to sign a licence for the restored research reactor at the Hahn-Meitner Institute. Ironically, she does not contend that the reactor itself presents a danger, but rather that the disposal of radioactive waste from the reactor is not and never will be assured as long as West Germany has no facilities for waste reprocessing and disposal.

The newly refurbished $10 \mathrm{MW}$ research reactor was meant to be used as a neutron source for biology, medicine and chemistry as well as physics, and was completed at a cost of DM170 million (about $\$ 110$ million) late last year. Since then, it has been consuming DM1.8 million a month in maintenance costs.

West German Research Minister Heinz Riesenhuber (Christian Democrat), whose ministry provides 90 per cent of the HMI budget, has threatened to withdraw support from HMI if the reactor is not licensed by 31 July. According to Hans Stiller, scientific director of HMI, if the reactor licence is denied, then there will be an exodus of researchers from the institute that could ultimately force it to close down.

Schreyer's refusal to license the reactor could be reversed when a new government is elected in West Berlin later this year, says Stiller, but such a move would certainly be challenged in court and the reactor would have to remain shut down in the meantime. Then the exodus of researchers would begin in earnest, he fears, because the wheels of justice turn "very slowly" in West Germany.

The only chance to save HMI, says Stiller, is for West Berlin Governing Mayor Walter Momper (Social Democrat) to remove from Schreyer the task of licensing the reactor. Stiller admits that this tactic would certainly bring down the fragile 18-month-old government coalition between the Social Democrats and the Alternative Liste.

Nevertheless, there are compelling reasons for Momper to risk the coalition in order to save HMI. Momper's Senator for Science, Barbara Riedmüller-Seel, writing in the West Berlin daily Der
Tagesspiegel, cites the reactor's "strategic importance" for science in West Berlin. If the HMI reactor is not licensed, she argues, the city will lose out when new research institutions are created. At risk would be the electron storage ring BESSY II, another politically controversial project opposed by Alternative Liste.

Momper has risked the break-up of the coalition on other issues recently, in anticipation of new elections encompassing both West and East Berlin. Alternative Liste support is bound to wither in the reunified city, where economic concerns will dominate over environmental ones. But Momper will have to act fast if he wants to dismiss Schreyer before her decision not to license the reactor is made final. She told HMI that it would have only until 6 August to raise objections to her decision.

Although the issue has dragged on ever since the Social Democratic-Alternative Liste coalition took power in West Berlin, it continues to mobilize the West German research community. In July, the chairman of the West German national laboratories, Harald zur Hausen, appealed to both Riesenhuber and Momper to prevent any further delay in licensing the reactor.

Stiller and the Social Democratic majority in the West Berlin Senate contend that waste disposal for the HMI reactor is already assured. HMI last year signed a contract with the British reprocessing facility at Dounreay to reprocess its waste, return the restored fuel rods, and leave the remaining waste there for 29 years, by which time West Germany will have found a place to put its own nuclear waste.

According to Stiller, West German law requires only six years of guaranteed storage, so the current HMI arrangement exceeds the legal minimum by 23 years. But Schreyer claims that transport over such long distances is too risky. West Germany needs a plan for long-term waste disposal now, she says, or else the operation of any nuclear reactor is irresponsible.

The repercussions of Schreyer's demand may reach far beyond the future of HMI, Stiller warns. There are other Länder with Social Democratic governments that would be only too happy to challenge the federal government in court over the issue of waste disposal.

The new Social Democratic-Green government in Lower Saxony has announced that it plans not to continue construction at Gorleben and Konrad, which were intended to become West Germany's only sites for final storage of high- and medium-level wastes respectively.

Steven Dickman

\section{Parlez-vous français?}

\section{Paris}

IN an attempt to halt the decline of French as a scientific language, the Ministry of Research and Technology and the National Institute of Health and Medical Research (INSERM) are offering two FF400,000 $(\$ 72,000)$ prizes for the best original papers published in French in the journal,

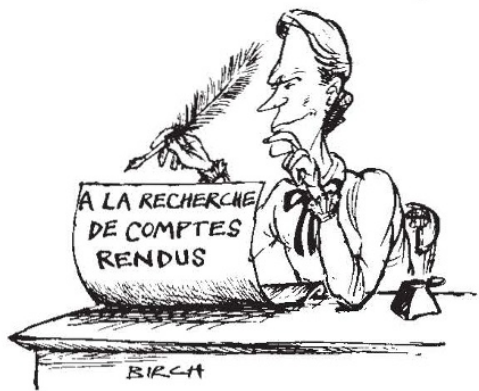

Comptes rendus de l'Académie des Sciences. Now that the Annals de l'Institut Pasteur is published in English, Comptes Rendus is the most respected science journal to be published in French - albeit with long abstracts in English.

Over the past decade, French scientists have gradually abandoned native journals in favour of international English-language journals. Recently, researchers in life sciences at CNRS, the national science research centre, were more or less told by their controversial director, Claude Paoletti, that only such publications would have any weight when it came to laboratory assessments for grants - a move now rather at odds with the ministry.

The new effort to improve the image of French language publications is also an act of defiance. There is a common feeling here that papers submitted to international journals are often rejected because the researchers are not American or English.

Peter Coles

INDIA

\section{Forest cover disappears}

\section{Bangalore}

INDIA has lost $1,907 \mathrm{sq}$. $\mathrm{km}$ of forest cover in the past four years according to the results of a new assessment made by the Forest Survey of India using Landsat data. An earlier assessment based on satellite imagery collected between 1981 and 1983 showed that the country then had a forest cover of $642,041 \mathrm{sq}$. $\mathrm{km}$. By 1985 to 1987 , the period on which the new assessment is based, forest cover had declined to 640,134 sq. km. Mangrove forest cover increased slightly from 4,000 sq. $\mathrm{km}$ to 4,200 sq. $\mathrm{km}$. According to India's Ministry of Environment, steps being taken to slow deforestation are provided by the National Forest Policy and Forest Conservation Act of $\mathbf{1 9 8 8}$ and include a centrally sponsored scheme to encourage the use of fuels other than wood. 